\title{
TAKAFUL MODELS: THEIR EVOLUTION AND FUTURE DIRECTION
}

\author{
Mohammad Mahbubi Ali*
}

\begin{abstract}
Takaful (Islamic insurance), being an important emerging sector in the Islamic financial industry, has exhibited remarkable growth across the globe over the last few decades. This indicates an enormous demand for takaful products, from short-term general takaful to long-term family takaful. As a result, takaful has attracted sizable attention from both Muslim and non-Muslim countries. Nevertheless, the industry continues to experience a plethora of contentious issues in its operational models. The present study explores the evolution of takaful models and their future direction.
\end{abstract}

Keywords: takaful, tabarru', underwriting surplus, musharakah ta'awuniyah

\section{Introduction}

Takaful (Islamic insurance) is an important emerging sector in the Islamic finance industry that has exhibited persistent, exciting growth in key markets, including the Gulf Cooperation Council (GCC) and Southeast Asia. ${ }^{1}$ It offers an alternative to conventional insurance, which the Shari'ah prohibits because it contains substantial uncertainty (gharar), features of gambling and riba (usury). By contrast, takaful is established upon the notions of mutual assistance (ta 'awun), mutual security and guarantee (tadamun), and mutual protection and assurance (takaful). It is also deeply rooted in the concept of tabarru' (donation), which tolerates the presence of ignorance and uncertainty. ${ }^{2}$ These basic principles underlying takaful have been used to construct various models and structures resembling conventional insurance.

Nevertheless, these takaful models, and since first being launched in 1979 in Sudan, have encountered substantial issues and contentions. This has triggered the evolution of a tremendous number of takaful models, all formed through a process of trial and error, with one model being introduced to supersede the previous in an effort to find the ideal takaful model. Considering this, the present study seeks to examine the evolution of takaful, the issues currently entangling its operation, and its future direction. Specifically, the study aims to achieve the following objectives: 
1. To discuss the concept of takaful from a Shari'ah perspective.

2. To delineate the evolution of takaful.

3. To identify the Shari'ah issues arising from current takaful models.

4. To chart the future direction of takaful.

Following this introduction, the study is organised as followings: section 2 examines takaful as a concept, with particular attention to what distinguishes it from conventional insurance; section 3 describes the various takaful models in greater detail, including their issues and evolution; section 4 charts the future direction of takaful; and the final section concludes the study.

\section{Takaful vis-a-vis Insurance}

Despite conventional insurance's noble objective of providing an instrument for risk management, Shari'ah prohibits it because it is structured around a contract of exchange ( $m u$ 'awadah) containing elements of riba, uncertainty and gambling. The issue of riba, for example, emerges in two forms. Firstly, conventional insurance is the exchange of money for money in unequal amounts and on a deferred basis. This is particularly true since the insurance benefit that the policyholders will receive is normally higher than the premium sum and contingent upon a defined future event. Secondly, the premium is invested in interest bearing instruments, such as treasury bills and fixed deposits in conventional banks. The feature of uncertainty, on the other hand, occurs in conventional insurance because both the right to the insurance benefit and its actual value are dependent upon the occurrence of catastrophe, which is uncertain. ${ }^{3}$ As for gambling, this occurs in conventional insurance as a consequence of the uncertainty, where the gain or loss is contingent on the presence or absence of claims.

Takaful is designed to offer a Shari'ah-compliant alternative to prohibited forms of conventional insurance through the application of tabarru'. The latter is a unilateral charitable contract, as opposed to a contract of exchange. In Islamic jurisprudence, the existence of uncertainty and ignorance nullifies a contract of exchange (mu'awadah) but is tolerated in tabarru' contracts. ${ }^{4}$ This is because the parties who enter into a tabarru' contract do not aim to make a profit out of the contributed sum, and hence the potential for dispute, which normally arises in a profit-making activity, vanishes. ${ }^{5}$ Operationally, the contributed sum is collected for the purpose of mutual assistance, when participants are faced with unforeseen future events. The introduction of tabarru' also resolves the issue of riba because its structure supersedes the exchange feature of conventional insurance and the contributed sum is only invested in Shari' ah-compliant business activities. ${ }^{6}$ 
The word "takaful" is derived from the root word kafala, which etymologically means 'guarantee' or 'indemnity'. Technically, takaful is a mutual form of insurance whereby a group of participants agree to contribute a sum in order to assist each other from a defined financial loss arising from a potential future catastrophe or misfortune. The Accounting and Auditing Organisation for Islamic Financial Institutions (AAOIFI) defines takaful as "a system through which the participants donate part or all of their contributions which are used to pay claims for damages suffered by some of the participants. The company's role is restricted to managing the insurance operations and investing the insurance contributions." The Islamic Financial Services Board (IFSB) defines it as "the Islamic counterpart of conventional insurance, and exists in both life (and family) and general forms, whereby it is based on the concept of mutual solidarity, and a typical takaful undertaking will consist of a two tier structure - hybrid of a mutual and a commercial form of company." In the same context, the Islamic Financial Services Act (IFSA) 2013 defines takaful as "an arrangement based on mutual assistance under which takaful participants agree to contribute to a common fund providing for mutual financial benefits payable to the takaful participants or their beneficiaries on the occurrence of a pre-agreed events."

In Islam, takaful is grounded in the notions of mutual assistance ( $\left.t a^{c} a w u n\right)$, mutual security and indemnity (tadhamun), and mutual protection and assurance (takaful), all of which are then incorporated into the concept of tabarru'. The principle of mutual assistance is deduced from a verse of the Holy Quran which reads: "Help one another in al-Birr and in al-Taqwa (virtue, righteousness and piety): but do not help one another in sin and transgression." ${ }^{, 10}$ It is also supported by a hadith that states: "Allah will always help His servant for as long as he helps others." 11 The notion of mutual security and indemnity is deeply rooted in the hadith of the Prophet (pbuh) that reads: "The place of relationships and feelings of people with faith, between each other, is just like the body; when one of its parts is afflicted with pain, then the rest of the body will be affected."12 Additionally, the spirit of mutual protection and assurance is substantiated by a hadith narrated by Imam Ahmad bin Hanbal, which reads: "By my life, which is in Allah's power, nobody will enter Paradise if he does not protect his neighbor who is in distress." 13

\section{Takaful Models: Evolution}

The main distinctive feature of takaful is the application of tabarru', which in this context entails a voluntary contribution by one person to another during 
the former's lifetime without expecting any compensation in return but which results in the transfer of the ownership of the contribution from the donor to the recipient. ${ }^{14}$ In light of this, the Shariah Advisory Council of Bank Negara Malaysia (SAC BNM) defines tabarru' as a contract of gratuity or charity, i.e. to relinquish a portion from the contribution as a donation to fulfill the obligation of mutual help, and to use it to pay any claim submitted by an eligible claimant. The tabarru' concept is applied to takaful in order to indicate the relationship between participants. ${ }^{15}$ The following subsections will explain in greater detail the contracts and models-alongside their issues and evolution-governing the relationship among participants and between participants and takaful operators.

\subsection{Contracts among Participants}

Tabarru', as just indicated, is the underlying concept defining the relationship between participants in a takaful scheme. It entails that each participant donates a sum of money to mutually assist and indemnify each other in the event of misfortune and catastrophe. The fund is pooled under a Participant Risk Fund (PRF) and treated as a "collective ownership" for the purpose of helping any participant who suffers financial loss arising from future calamities. In practice, however, the purpose of the agreement is not skewed merely towards providing mutual protection, but may also include both investment and savings. This is particularly true in the case of family takaful. Therefore, instead of a single fund, takaful operators will normally divide the fund into two: the Participant Risk Fund (PRF) and the Participant Investment Fund (PIF). PRF is a pool of tabarru' funds, while PIF is a fund dedicated to investment purposes.

Jurists unanimously agree that tabarru' is a noble concept in Islam. Its practice in takaful, however, remains a matter of contention. This is because the contributions paid by the participants may not be a donation in the pure sense, but rather a conditional donation: each participant donates a particular amount in order to entitle him or her to a future financial benefit. The contribution (donation) is imposed "in exchange" for that future benefit. Moreover, the rate of donation is adjusted in accordance with the participants' risk: the higher the risk exposure, the higher the contribution. This is problematic from the Shari'ah point of view because the amount given as tabarru' is supposed to be voluntary, not compulsory. Moreover, it is argued that if a participant reserves the right to claim compensation for a contributed sum, doing so will change the structure of takaful into a bilateral contract ( $\mathrm{mu}^{c}$ awadah): exchange of money in the form of a donation with money in the form of a claim/takaful benefit. If that is the case, the issues of riba, gharar and maysir re-emerge. 
Some scholars note that making something that should be voluntary into an obligation is permissible under the Maliki school of thought. In such cases, the participants' contribution is characterised as al-iltizam bi al-tabarruc (selfcommitment to donate). Under this concept, one who commits himself to do good things is obliged to do so. Some scholars dismiss this understanding, however, as it comprises of two commitments, donation and indemnification, thereby ultimately leading to a bilateral contract. Nevertheless, this dismissal is further disputed because, although it comprises both donation and indemnification, the latter is not definite because it depends on the occurrence of a catastrophe. ${ }^{16}$ Thus, it cannot be simply equated to an exchange or bilateral contract.

Some jurists construe the concept of tabarru' in takaful as hibah bi al-thawab (a gift with consideration). This is because the contribution made by participants is the 'price' for indemnification. Ibn "Arafat defines hibah bi al-thawab as "a gift for which financial compensation is intended." ${ }^{\prime 17}$ Al-Adawi, on the other hand, defines hibah bi al-thawab as "one person gives his asset to another so that he will give him consideration for it." 18 In Islamic jurisprudence, hibah is a form of tabarru' intended for charity and mutual assistance, rather than for seeking profit or an expected return. Thus, if the hibah is given in return for certain considerations, the majority of jurists ${ }^{19}$ will consider it to have shifted from a unilateral contract to an exchange contract. ${ }^{20}$ Some jurists, however, maintain the view that hibah bi-thawab remains a unilateral contract with all its rulings and legal implications. A narration in the Hanbali School, as quoted by Ibn Qudamah, states: "A [second] narration from Ahmad [ibn Hanbal] implies that the ruling of hibah in hibah al-thawab prevails [over the ruling of exchange contract]. Therefore, the rulings specific to sale contracts do not apply to it". ${ }^{21}$ Al-Mardawi cites al-Qadi's view stating that: "[Hibah al-thawab] is not a sale contract because hibah may sometimes be given purely as charity and may sometimes be given for a consideration." 22 Al-Sharbini quoted two views from the Shafi'i school regarding one who gives hibah that requires an unknown consideration. One of the views states that this form of hibah is valid as hibah, not as bay (sale). ${ }^{23}$

Some scholars, instead of considering al-iltizam bi al-tabarruc or hibah bithawab, introduce the concept of waqf as the underlying fiqhi characteristic of tabarru' in the context of takaful operation. In this context, al-iltizam bi altabarru $^{c}$ as promulgated by the Maliki school of thought is the most internationally accepted fiqhi characteristic of tabarru' in the context of takaful operation. AAOIFI, in its Shari'ah standard No. 26 Article 3, states:

Islamic insurance is based on the commitment of the participant to make donations for the sake of their own interest. The participants, therefore, 
protect their group by payment of contribution[s] that constitute the resources of the insurance fund, and assign the management of that fund to a committee of policyholders or to a joint stock company that possesses the license [for] practicing insurance business. In the latter case, the company assumes this job on the basis of a remunerated wakala (agency) contract. In addition to managing the insurance operations, the committee policyholders or the company also assumes the responsibility of investing the assets of the fund through mudharabah or investment agency. ${ }^{24}$

In the subsequent article, the standard states that: "the relationship between the policy holder and the fund takes the form of donation commitment at the stage of making contribution, and indemnification commitment at the stage of providing compensation for injury as per regulations and underlying constituent documents. ${ }^{25}$

\subsection{Contracts between Participants and Takaful Operators}

The takaful industry has experimented with various models and contracts underlying the relationship between participants and takaful operators. The following passages delineate the evolution of these various takaful models and the issues surrounding their practice.

\subsubsection{The Mudharabah Model}

AAOIFI defines mudharabah as a partnership in profit whereby one party provides capital and the other party provides labour. Any profit is shared between the capital provider and manager in accordance with a profit sharing ratio agreed upfront. Any financial loss will be borne solely by the capital provider, unless the loss is due to the manager's negligence (taqsir), misconduct (ta'addi), or a breach of terms (mukhalafah al-shurut). ${ }^{26}$

Mudharabah was the first model employed by the takaful industry in Malaysia. In this model, the takaful operator serves as a manager (mudharib) while participants are capital providers ( $r a b b a l-m a l)$. The operator will accept contributions from participants, which are then managed and invested in a Shari'ah compliant manner. The contract specifies that any profit from managing the fund will be shared between the takaful operator and the participants based on a ratio agreed upfront. In the event of loss or deficit in the PRF, however, the takaful operator shall provide an interest free loan (qard) that should be repaid when the PRF generates profit. ${ }^{27}$ The underwriting surplus, ${ }^{28}$ if any, will be distributed to the participants. Figure 1 depicts the process flow of the mudharabah model in the context of a family takaful product. 


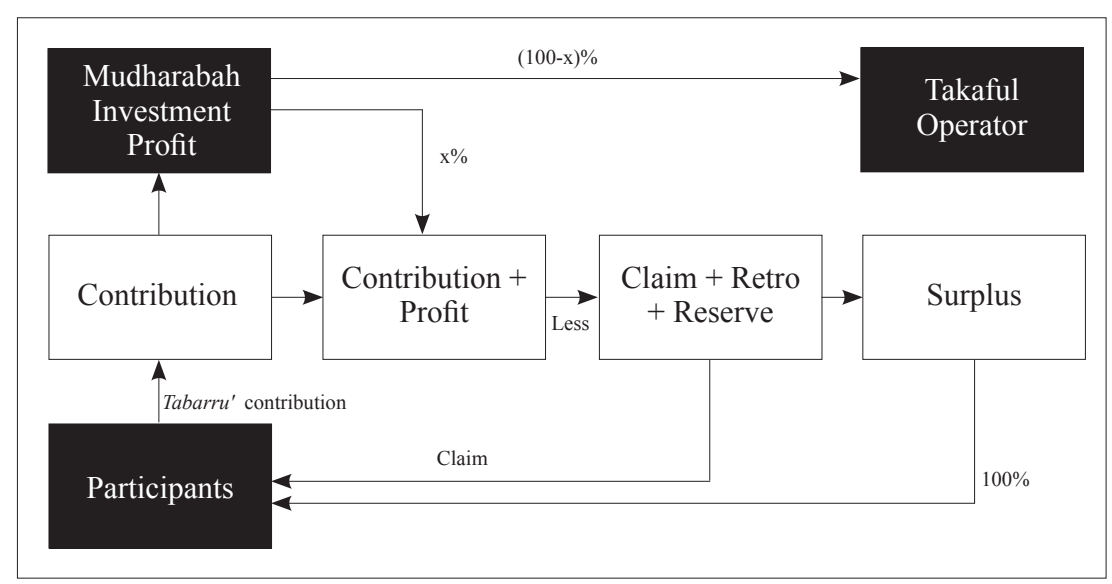

Figure 1: Mudharabah Model

The mudharabah model allows takaful operators to share in profit in line with a pre-agreed ratio but not in underwriting surplus. The absence of surplus sharing renders this model commercially unviable. This model, therefore, was altered to become a modified mudharabah which construed the underwriting surplus as the 'mudharabah profit'. ${ }^{29}$ Operationally, this allowed the profit from investment activities to be pooled into the PRF, from where it could be used for claims, retakaful and reserves. The remaining balance was then treated as the underwriting surplus and shared between the takaful operator and participants at an agreed ratio. Figure 2 shows the operational flow of the modified mudharabah model.

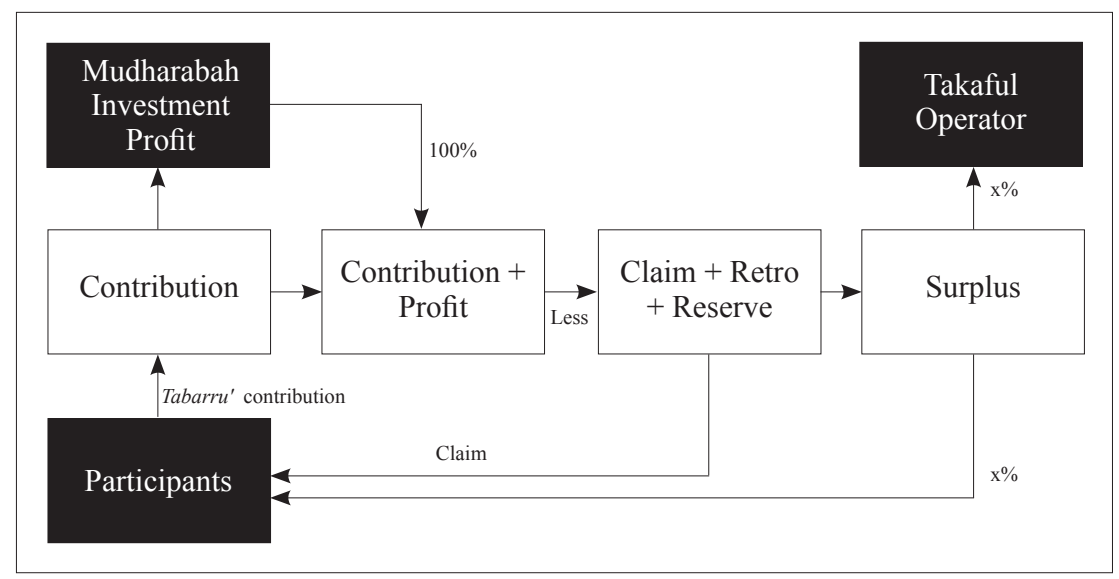

Figure 2: Modified Mudharabah Model 
The application of the mudharabah model within the takaful industry has provoked considerable criticism. Ayub argued that the mudharabah concept is highly suitable for banking but not for insurance. ${ }^{30}$ Takaful, he argued, is established on the notion of mutual assistance and achieving societal goals, while mudharabah is a commercial-based contract. They are therefore two different concepts with completely different objectives. Ultimately, the application of mudharabah in the context of takaful brought some questions to the fore. Firstly, from the Shari'ah point of view, is it possible to treat tabarru' contributions concomitantly as mudharabah capital? For instance, tabarru' causes the relinquishment of the donor's ownership, while in a mudharabah contract the capital providers retain ownership. Second, in the case of a deficit, does obliging the takaful operator to inject money into the fund go against the essential concept of mudharabah? A mudharabah contract is a trust contract in which the operator is a trustee-manager and not a capital guarantor. Third, in the modified mudharabah model, is it permissible for takaful operators to take a portion of the surplus, and as is practiced by their conventional counterparts? Is, in other words, the surplus equivalent to profit? While profit is the positive outcome of a business activity, surplus is the accumulation of profit and what is left of contributions after deductions for claims, reserves and retakaful.

\subsubsection{The Wakalah Model}

The substantial criticisms and Shari'ah issues associated with the mudharabah model pushed Shari'ah scholars and industry players to search for an alternative. As a result, they introduced the wakalah model, which takaful operators have gradually adopted. Wakalah is an agency contract whereby a party mandates another party as their agent to perform a particular task. Under this model, the takaful operator serves as an agent charged with managing and investing the contributions of their participants and, in compensation, will enjoy a predetermined fee. The profit and underwriting surplus, if any, will be fully distributed to participants. Figure 3 exhibits the operational flow of this model. 


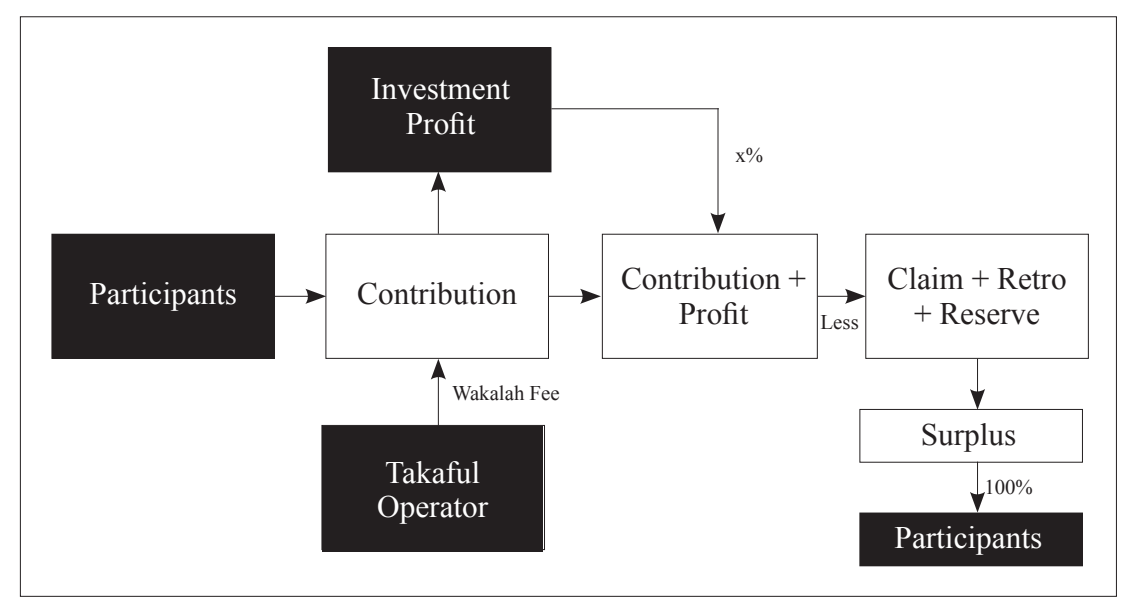

Figure 3: Wakalah Model

In its purest form, however, the wakalah model is commercially unattractive for operators; the absence of any surplus sharing makes it unviable and has led to calls for it to be revisited. As a result, the original model has indeed been modified. In the modified version, the operator, and in addition to their entitlement to a wakalah fee, takes a portion of the underwriting surplus based on performance. Figure 4 illustrates the process flow of this modified wakalah model.

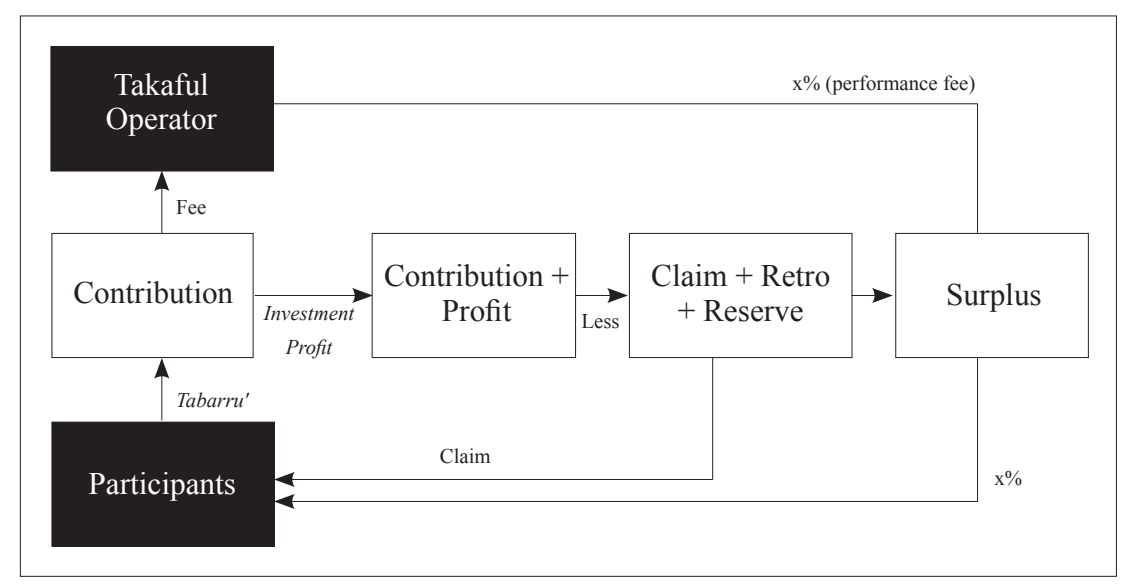

Figure 4: Modified Wakalah Model 
At the time the model was first introduced in Malaysia, operators took $90 \%$ of the surplus, with only $10 \%$ going to participants. This division was also applied in Saudi Arabia, where it remains in practice until the present. ${ }^{31}$ In both places, however, it has triggered criticism: many considered the way surplus is being shared as exploitative and unjust. In response, the Central Bank of Malaysia issued guidance in the form of the Takaful Operator Framework (TOF) 2010. This stipulated that the total amount of incentive fee from the PRF payable to the takaful operators should not exceed the amount of surplus paid or accrued to participants. ${ }^{32}$ In other words, a takaful operator's share of the surplus is limited to a maximum of $50 \%$.

Despite the issuance of TOF, the practice of surplus sharing under the modified wakalah model still raises concerns. This is largely because the performance fee is based on the operator's capacity to underwrite the PRF. This criterion is difficult to measure and easy to manipulate. For example, to generate a large surplus the operators can make claims difficult, thereby reducing the reserve portion and/or minimising the retakaful contribution. Many argue that it would be fairer if the performance fee were based on the operator's ability to manage the investment fund effectively. For example, if the operator were able to generate a profit rate above $10 \%$, they could keep the excess as a performance fee.

\subsubsection{The Hybrid Model}

In view of the substantial criticisms directed at the practice of surplus sharing and the possibility of adopting a performance fee, industry players developed a new model: a combination of mudharabah and wakalah called 'the hybrid model'. This model is normally applied to family takaful products and divides the participants' fund into two pools: PRF and PIF. The model employs a wakalah contract to govern the operator's role in managing the PRF, while a mudharabah contract is used to explain the operator's capacity as an investment manager for the PIF. As compensation, the operator reserves the right to a predetermined fee for managing the PRF and a profit share for managing the PIF. In this model, the issue of surplus does not arise because all surplus is supposed to be returned to the participants. Only a performance fee is taken from the PIF. Some takaful operators, however, still take a portion of the surplus from the PRF as an incentive. Figure 5 illustrates the hybrid model. 


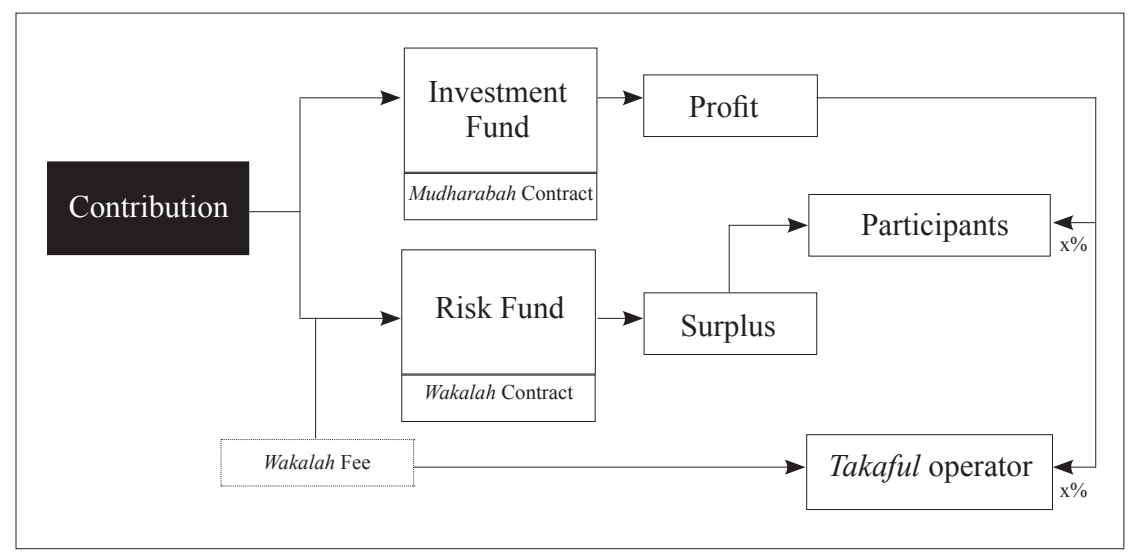

Figure 5: Hybrid of Wakalah and Mudharabah Model

\subsubsection{The Waqf Model}

Mufti Taqi Usmani, a renowned Pakistani Shari'ah scholar, has developed a combined cash waqf and wakalah contract model for takaful. This model has been successfully implemented in Pakistan and South Africa. In essence, it aims to enable individuals to assist each other in the event of catastrophe by using a waqf fund. The shareholders in a takaful company will initially place donations in order to facilitate the establishment of the waqf fund. Simultaneously, participants contribute a sum of endowment to the fund. Thus, the fund consists of two sources: a fund established by the shareholders and another established by the participants. Throughout the process, the takaful operator serves as an agent (wakil) for both shareholders and participants, helping to administer the fund and pay claims. Concomitantly, they act as an investment agent to help invest the fund in Shari'ah-approved business activities. As payment, the operator will be entitled to a certain percentage of a predetermined wakalah fee in addition to a performance fee. ${ }^{33}$ The proceeds of the waqf fund will be used to assist any participant who experiences misfortune and/or catastrophe. ${ }^{34}$ Figure 6 illustrates the process flow of this hybrid wakalah and waqf model. 


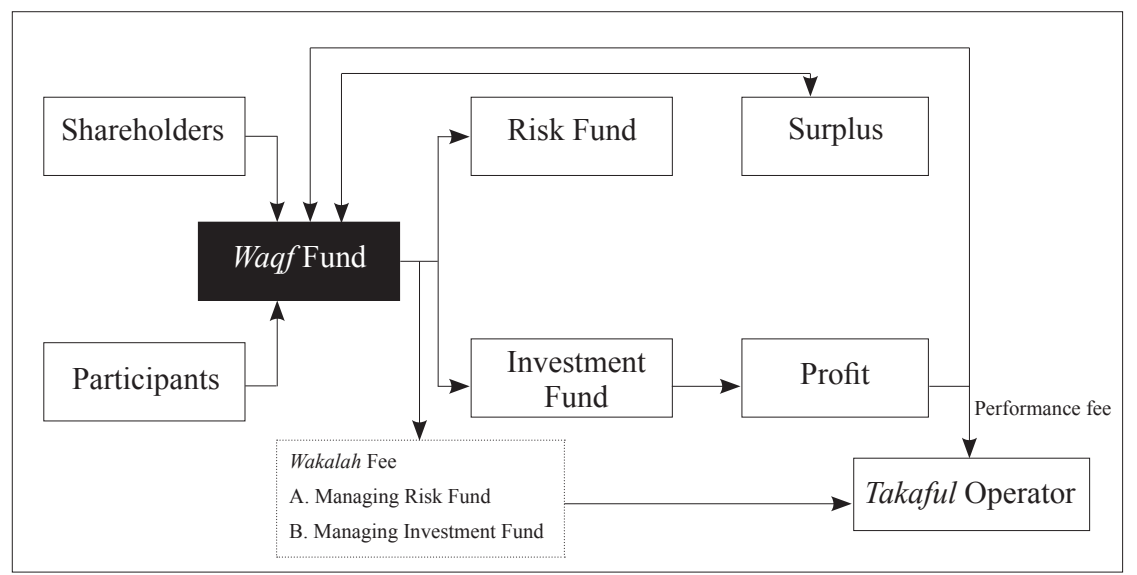

Figure 6: Hybrid of Wakalah and Waqf Model

There are at least three main concerns surrounding the application of this model. First, the introduction of cash waqf into the operation of takaful undermines the fundamental objective of waqf. Thus, waqf should ideally provide benefit for both the poor and the rich. In takaful, however, only the rich (participants) will benefit. ${ }^{35}$ Second, inflation and the possibility of loss when investing the waqf fund could diminish the value of that fund, contradicting the perpetual nature of waqf. Third, and finally, in the Malaysian context the application of this waqf model would face restrictions because waqf is traditionally administered and governed by the states. ${ }^{36}$

\section{Takaful Models: Future Direction}

In 2010, the International Islamic Fiqh Academy (IIFA), a subsidiary organ of the Organisation of Islamic Cooperation (OIC), in its conference on "Cooperative Insurance: Dimensions, Perspectives, and the Position of the Islamic Shari'ah" held in Amman, called for a re-examination of the fiqhi characteristics of tabarru' when used in takaful. This call was reiterated in its $20^{\text {th }}$ session, held in Algeria from 13-18 September 2012, and further reinforced in its $21^{\text {st }}$ session in Riyadh, held from 22-28 November 2013. ${ }^{37}$

The main issue discussed during these conferences was the ownership of the tabarru' fund used in takaful, which could affect treatments of underwriting surplus. SAC BNM, for example, allows the distribution of underwriting surplus to be shared between participants and takaful operators based on the terms of a 
mutual agreement. This is on the basis that, since the participants have donated the contribution as tabarru', they lose ownership of it as prescribed by the rules of hibah in the Shari'ah. As Ibn Qudamah points out, hibah requires the donor to relinquish ownership of the object of hibah and transfer it to the beneficiary. Based on these premises, it is argued that the donor (participant) has no right or claim over the contributions they make unless it is stipulated in the agreement that any surplus from the contributions can be exclusively given to them. Otherwise, the distribution of surplus will be based on the agreement and conditions stipulated in the contract, meaning the takaful operator may take a share. ${ }^{38}$ This corresponds to the legal maxim:

The fundamental [requirement for the validity of a contract] is the consent of the contracting parties, and its effects are the rights and duties they agree to. ${ }^{39}$

This signifies the recognition by the Shari'ah of the freedom of contract and the flexibility of contractual stipulations and agreements so long as they do not conflict with the inherent nature and the fundamental objective of contract.

The SAC BNM position concerning the underwriting surplus is, however, disputed by a number of international standards and fatwa-issuing bodies. Dallah al-Barakah, for example, in its Fatawa Ta'min (1986), resolved that the underwriting surplus is the exclusive right of the participants, meaning that it should be returned to them. The takaful operator therefore has no right to enjoy a portion of the surplus. The AAIOFI Standard on takaful states:

The underwriting surplus and its returns, less expenses, and payment of claims, remain the property (milk) of the policyholders, which is the distributable surplus. This is not applied in commercial insurance, where the premiums become the property of the (insurance) company, by virtue of contract and acquisition, which would make it revenue and a profit for commercial insurance. ${ }^{40}$

To overcome the issue of ownership in the underwriting surplus, some scholars propose the application of a wadiah yad dhamanah (safekeeping with guarantee) model for the operation of takaful. Under this model, the takaful operator acts as a custodian or depository institution with whom participants place their fund as a deposit, coupled with a waiver clause to release some amount of the deposit for the purpose of indemnifying other participants. Under this concept, the participants maintain ownership of the fund and the issue of surplus distribution is thus resolved. ${ }^{41}$

Another proposal is the application of a 'conditional contribution' scheme to a cooperative fund. Under this concept, participants will contribute funds 
for mutual assistance with the condition that any surplus be redistributed to participants. The concept therefore allows participants to retain the ownership of any surplus. ${ }^{42}$

Others believe that the best model for the operation of takaful is the one practiced by the Prophet (pbuh) and his Companions based on the concept of tanahud or nihd (share in expenses). Under this concept, each member of a travel group contributes some funds and/or food to cover their needs during a journey. Although the contributions may vary from one person to another, the surplus (if any) will be shared equally. ${ }^{43}$ This concept is deeply rooted in the hadith which reads:

When the Ash'aris run short of provisions in campaigns or run short of food for their children in Madinah, they collect whatever is with them in a cloth and then partake equally from a vessel. ${ }^{44}$

In the context of takaful, the concept of tanahud or nahd takes the form of musharakah ta'awuniyyah (cooperative partnership) - that is, a contract of cooperation and shared responsibility for mutual assistance with the objective of allowing indemnification to be given when needed, while eliminating the intention of some participants to profit from others. The calculation of contributions may differ from one person to another and the net contribution may remain unknown until ex-post dividends are paid..$^{45}$ This concept of musharakah ta'awuniyyah was first proposed at the aforementioned IIFA Conferences. ${ }^{46}$ In response, in 2014 the International Shari'ah Research Academy for Islamic Finance (ISRA) Malaysia

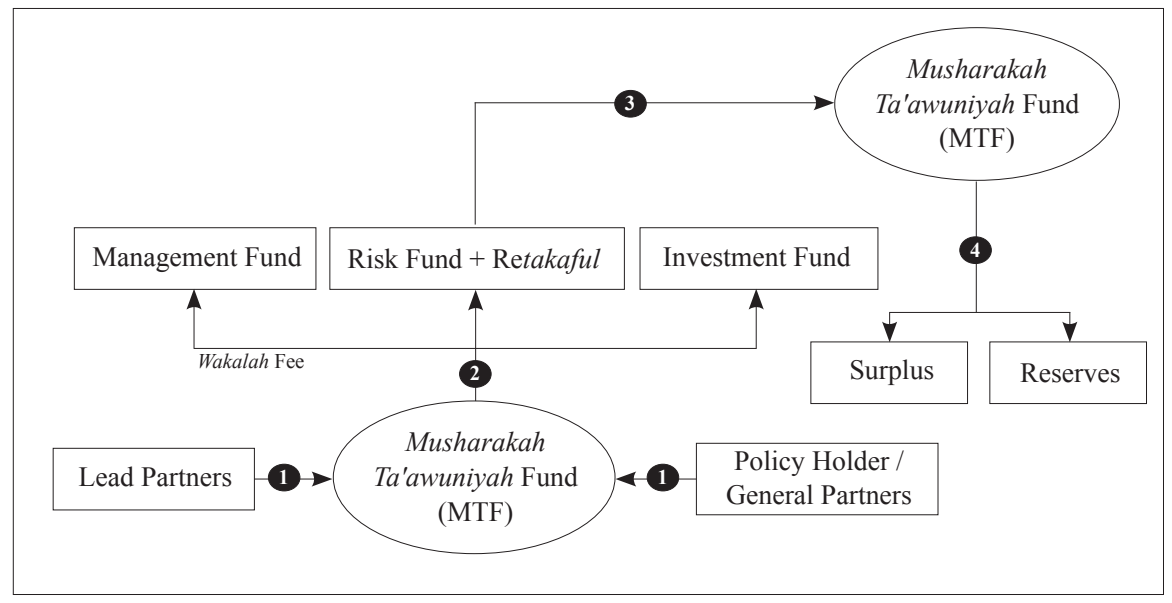

Figure 7: Modus Operandi of Musharakah Ta'awuniyah

Source: Ahmad, ISRA (2014) 
designed a takaful model based on its precepts, as depicted in figure 7 below: Explanation:

1. Participants (lead and general partners) ${ }^{47}$ contribute capital under the musharakah ta'awuniyah scheme, which is then pooled into the Musharakah Ta'awuniyah Fund (MTF).

2. The MTF is divided into: a Management Fund for running the MTF's affairs; the Risk/Retakaful Fund for payment of claims and retakaful contributions; and an Investment Fund. In this structure, the takaful operator is entitled to a wakalah fee for managing the funds.

3. Risk/Retakaful Funds will be used to pay claims and retakaful contributions.

4. Any amount of the fund over and above what is required for the payment of claims is to be kept in reserve to provide a cushion for the payment of abnormal claims due to any calamity. The underwriting surplus over the claims, retakaful contributions and reserves, will be distributed to the lead and general partners at the end of the financial year. In case of a deficit in the MTF, the lead and general partners will inject funds.

\section{Conclusion}

Takaful has evolved and progressed tremendously in recent years. Nevertheless, some contentious Shari'ah issues continue to plague the various takaful models currently in use, and which require serious attention. Finding an ideal takaful model is 'the homework' of scholars, researchers, and industry players. Extensive research and deep study are essential in order to derive an ideal model for takaful operationalisation, a model that serves as a bridge for achieving the noble objectives of the Shari'ah.

The present study explored the evolution of various takaful models and the Shari'ah issues entangling them. The study revealed that the treatment of underwriting surplus was one of the main triggering factors behind the evolution of the various takaful models through a trial and error approach — one model was introduced to supersede another.

In conclusion, the study advocates musharakah ta'awuniyah, a concept deeply rooted in the Prophetic tradition under the notion of tanahud. However, the study acknowledges a potential gap between the proposed model and the requirements of business. Further study is therefore needed to examine the commercial viability and practicality of the proposed model, taking into consideration its operational and technical concerns, such as pricing, underwriting, actuary and the like. 


\section{Notes}

* Mohammad Mahbubi Ali is a Research Fellow at the International Institute of Advanced Islamic Studies (IAIS) Malaysia. He can be contacted at mahbubi@ iais.org.my.

1. MIFC, (2015). Takaful: Growing from Strength to Strength. MIFC: Kuala Lumpur, 25 November 2015, p. 1.

2. Khorshid, A. (2004). Islamic Insurance: A Modern Approach to Islamic Banking. London: Taylor \& Francis, p. 61.

3. Engku Ali, R.A (2010). Panduan Asas Takaful: Panduan Tentang Falsafah \& Prinsip Takaful Berdasarkan Shari'ah. Kuala Lumpur: CERT, pp. 21-24.

4. Dusuki, et.al. (2012). The Application of the Wadiah Concept in Traditional Family Takaful Products. ISRA Research Paper, No. 35/2012, p. 2.

5. Ibid, p. 2.

6. Engku Ali, R.A (2010). Panduan Asas Takaful: Panduan Tentang Falsafah \& Prinsip Takaful Berdasarkan Shari'ah. Kuala Lumpur: CERT, pp. 48-49.

7. AAOIFI (2004). Accounting, Auditing \& Governance Standards (for Islamic Financial Institutions), English version. Bahrain, Financial Accounting Standard No. 12, Appendix E, p. 5.

8. IFSB (Dec, 2009). Guiding Principles on Governance for Takaful (Islamic Insurance) Undertaking. IFSB: Kuala Lumpur, p. 2.

9. Government of Malaysia, (2013). Law of Malaysia Act 759 Islamic Financial Services Act 2013, p. 36.

10. Al-Ma'idah [5]: 2.

11. Al-Naisaburi, M. (n.d). Shahih Muslim. Beirut: Dar Ihya' al-Turath al-Arabi, 4/2074, hadith no. 2699.

12. Al-Bukhari (1422AH). Shahih al-Bukhari. Dar Thuq al-Najah, 8/10, hadith no. 6011.

13. Al-Naisaburi, M. (n.d). Shahih Muslim. Beirut: Dar Ihya' al-Turath al-Arabi, $1 / 68$, hadith no. 46.

14. Parid, N. (2009). "Insurable Interest in Takaful Practices : An Analysis". ISRA Research Paper, no. 03/2009, p. 13.

15. Bank Negara Malaysia, (2010). Resolusi Syariah dalam Kewangan Islam, Kuala Lumpur: BNM, second edition, p. 62.

16. Muhammad, M. (2010). Musharakah Ta'awuniyah for Takaful Operation, ISRA bulletin, vol. 06/0ct 10, p 10-11.

17. Al-Rassa ${ }^{c}$ (1350H). Sharh Hudud Ibn ${ }^{c}$ Arafah. Al-Maktabah al-cIlmiyyah. p. 427.

18. Al-'Adawi.(1414H). Hashiyah al-c ${ }^{c}$ Adawi ${ }^{\circ}$ Ala Sharh Kifayah al-Talib alRabbani. Beirut: Dar al-Fikr. pp. 2/260

19. Al-Sarakhsi, 1414H, 14:141; Ibn Anas, 1415H, 4:382; Al-Nawawi, 1425H, 172.

20. Ali, M.M (2014). Exploring a Shari'ah Compliant Model for Retirement Annuity Plan. ISRA Research Paper No. 67/2014, p. 20.

21. Ibn Qudamah, ${ }^{\mathrm{C}}$ Abdullah Aḥmad Muḥammad al-Maqdisi.(2004). Al-Mughni. Cairo: Dar al-Hadith, 2:261.

22. Al-Mardawi, 'Ala' al-Din 'Ali ibn Sulayman.(n.d). Al-Insaffi Macifah al-Rajih min al-Khilaf. Dar Ihya' al-Turath al-'Arabi, pp. 7/116. 
23. Al-Sharbini (1415H). Mughni al-Muhtaj. Beirut: Dār al-Kutub al-'lmiyyah, 3:573.

24. AAOIFI (2010), Shariah Standard for Islamic Financial Institutions, Manama: AAOIFI, p. 465.

25. AAOIFI, 2010. In No 26 article 4 (c), p. 465.

26. AAOIFI, 2010, p. 235-236.

27. Dusuki, A.W (ed.) (2011). Islamic Financial System, Principles and Operations, Kuala Lumpur: ISRA, p. 517.

28. AAOIFI (2010) in its Accounting Standard No. 13 defines underwriting surplus as, "the excess of the total premium/contributions paid by policyholders during the financial period over the total indemnities paid in respect of claims incurred during the period, net of reinsurance and after deducting expenses and changes in technical provisions" (AAOIFI, 2010, p. 409).

29. Engku Ali, R.A. \& Odierno, H.S. P. (2008). Essentials Guide to Takaful (Islamic Insurance). Kuala Lumpur: CERT, p. 46.

30. Ayub, M (2007). Understanding Islamic Finance. NYSE. John Wiley \& Sons, p. 426.

31. Alpen Capital (2010), GCC Takaful Industry Report. 12 January 2010, p. 24.

32. BNM. (2010). Takaful Operational Framework. Kuala Lumpur: Bank Negara Malaysia, p. 17.

33. Ibid, p. 15.

34. Dusuki, (ed.), 2011, pp. 523-524.

35. Muhammad, M., 2010, pp. 10-11.

36. Federal Constitution, 2010, Article 74 Clause 2 Item 1 State List.

37. Ahmad, AUF. (2014). Exploring the Model of Musharakah Ta'awuniyah in Takaful. ISRA Research Paper no. 71/2014, p. 6.

38. Tobiaz Frenz \& Yousnes Soualhi, (2010). Takaful and Retakaful: Advanced Principles and Practices, Kuala Lumpur: IBFIM \& Munich Re, p. 174.

39. Laldin, Mohammad Akram, et. al. (2013). Islamic Legal Maxims and Their Application in Islamic Finance. Kuala Lumpur: ISRA, p. 26.

40. AAOIFI (2010), p. 437.

41. Bouheraoua, S \& Ahmad, M.A (2011) Takaful Operation: Appraisal of the Existing Models and Exploration of a Possible Alternative, the Wadi'ah Model. Revue des Sciences āconomiques et de Gestion $N^{\circ} 11,2011$, p. 11-26.

42. Frenz \& Soulhi (2010), p. 175.

43. Al-'Aini, Abu Muhammad Mahmud bin Ahmad (n.d), 'Umdat al-Qari Sharh Shahih al-Bukhari, Beirut: Dar Ihya' al-Turath al-Arabi, 13/40.

44. A-Bukhari, Muhammad bin Ismail. (1422AH). Shahih al-Bukhari. Dar Tuq alNajah, hadith no. 2486.

45. Ahmad, AUF. (2014). p. 15.

46. Ibid., p. 6.

47. Lead partners are the relevant industry/sector players and the group of people who established the MTF. They provide the minimum required capital. The general partners are the general participants who contribute to the MTF based on the amount determined by actuaries, as mutually agreed upon in an approved plan (Ahmad, 2014). 